\title{
Bet Low: An Active Career
}

\section{Jenny Brownrigg}

Exhibitions, Glasgow School of Art, Glasgow, Scotland

J.Brownrigg@gsa.ac.uk

Jenny Brownrigg is a curator and writer. She is Exhibitions Director at the Glasgow School of Art (2009-). Brownrigg's research interests include modern and contemporary Scottish women artists. Her forthcoming exhibition focuses on on early Twentiethcentury women documentary photographers and filmmakers in Scotland. 


\section{Bet Low: An Active Career}

In the early part of her career, Bet Low's (1924-2007) work captured city scenes and people, before she turned her attention to landscape painting.. Low then developed a uniquely figurative style, visually reducing landscape into key elements. Running concurrent with her artistic practice, Low's early working experience at Glasgow Unity Theatre and involvement in artist-led groups led to her co-founding the New Charing Cross Gallery (1963-8), Glasgow with John Taylor (born 1936). Although she was an independent artist actively working outside any institutional context, Low did not consider herself 'unknown'. Following Low's own understanding of her public profile, this research considers the visibility of her practice, arguing that the idea of an 'unknown' woman artist may be a projection in relation to Low's career in particular, concluding with a consideration of her critical legacy.

Keywords: Bet Low, Twentieth century art, Scotland, landscape, painting

\section{Introduction}

This article maps development of Bet Low's(born Gourock 1924, died Glasgow 2007) career, both in terms of her grassroots collaborative endeavours as well as the the themes and subjects of her art practice, from city to landscape. Like her contemporary Joan Eardley, Low's practice also spanned both central (Glasgow) and peripheral locations (the Orkney island of Hoy). Whether chance observations of 'real' people encountered on Glasgow streets or the shifting relationship of weather interacting with the landmasses of Orkney, Low's work sought to return time and time again to significant places to capture the transient forces that animated their nature.

Bet Low attended Glasgow School of Art (1942-1945), during the period of the Second World War, with contemporaries including Joan Eardley (1921-1963), Ian Hamilton Finlay (1925-2006) and Cordelia Oliver (1923-2009). Following a threemonth diploma course at Hospitalfield College of Art, Arbroath and teacher training at Jordanhill Training College, Glasgow (1945-6) [1], Low found her first real place of 
inspiration in the creative ethos and interdisciplinary milieu of Glasgow Unity Theatre. Due to depleted numbers of established actors, because of World War Two National Service, a range of diverse individuals came together to form a left-leaning theatre group Glasgow Unity Theatre [2]. This included former members of the Glasgow Corporation Transport Players, Jewish Institute Players, Clarion Players and the Glasgow Worker's Theatre Group. Low helped paint set scenery, did occasional set design and assisted on publicity. She went on to marry Tom Macdonald (1914-1985), an artist set-designer at the theatre, who she collaborated with on a further two initiatives that shared a similar manifesto of taking art to the people. Firstly, Low formed the Clyde Group with Macdonald and William Senior, staging the Art and Peace Festival and exhibition in McLellan Galleries, Glasgow in September 1948. [3] Low and Macdonald then co-organised an open air exhibition on the railings of Glasgow's Botanic Gardens in 1957 [4]. Low then went on to co-found and direct the New Charing Cross Gallery (1963-68) with artist John Taylor (1936-) and latterly art collector Cyril Gerber (1917-2012) as Low and Taylor perceived a lack of galleries in Glasgow showing the work of emergent modern painters. The New Charing Cross Gallery, situated on a floor above a busy printers' premises on Glasgow's Sauchiehall Street, sought to both platform and market such work. Although Low was working outside of an institutional context, in 1964 she was elected a Professional Member of the Society of Scottish Artists and also an invited Professional Member of the Scottish Society of Women Artists.

While Glasgow was to remain home, Low and Macdonald bought a small cottage on the island of Hoy, Orkney in 1967 [5]. This sustained relationship to place impacted greatly on her practice and she moved on to develop a unique style of figurative landscape painting and understanding of colour, reducing land, sea, sky and 
weather to simple elements that define a particular moment. The method Low developed was to visually notate particular views in sketch form, with written notes directly onto the drawings, often recording colour, composition and time of day. These sketches were then utilised to re-enter the scene and make paintings from when she returned to her Glasgow studio. Her later pencil studies captured light itself, such as sun cutting through mist or silhouettes of landmasses emerging through fog.

Championed in particular by Cyril Gerber, who went on to set up the Compass Gallery in 1969 after the New Charing Cross Gallery closed, Low had several solo shows throughCyril Gerber Fine Art, including The Forties, Glasgow people and places drawings and paintings, Tom Macdonald \& Bet Low (1984). In 1985 she had a significant retrospective, selected by Cordelia Oliver, at Third Eye Centre, Glasgow, which toured Scotland to Dumfries, Perth and Stromness. Her work was acquired for both public and private collections in her lifetime. Reminiscent of her aims to support artists in her earlier career with New Charing Cross Gallery, in 1994 Low established the Bet Low Trust which awards scholarships to artists in Scotland. Following her death in 2007, Low's work has been selected for several survey shows of women artists in Scotland however this essay considers whether or not the 'salvage' survey exhibition, where once overlooked artists, genders or even geographical creative loci are latterly represented, is limited as a model when presenting Low's work. In terms of the development of her critical legacy how can we utilise new readings of her oeuvre? Her work has been increasingly recognised by, or read in conjunction with, a new generation of contemporary artists, such as Karla Black at Inverleith House, Edinburgh (2010),, which begins to provide new readings of Low's oeuvre. These new connections by creating a discursive visual space between works, begin to engage with the content of 
Low's paintings and her methods, moving her work beyond the category of being simply an, albeit latterly, overlooked Scottish woman painter.

\section{1940s' and Glasgow Unity Theatre}

Low's early work from the 1940's and early 1950's captured Glasgow city scenes and people, drawing on her local knowledge of the city's environs of Garnethill, Townhead, Cowcaddens and the Gorbals [6]. During her time at Glasgow Unity Theatre she created portraits of theatre hands such as Old Larry Odd Job Man alongside studies of actresses and a director in an egalitarian series [7] which mostly drew on the people and places of 'backstage' Glasgow. Her black and white expressionistic artworks, made with a variety of mediums including lino cut, black chalk, Indian ink, oil or black Conte Crayon, capture chimney sweeps, Down and Outs [8], pub singers, street musicians, methylated spirits drinkers and street vendors. This social realist approach was reflective of the work of her peers, including her husband Tom Macdonald, Joan Eardley and Louise Annand (1915-2012) who sought out a Glasgow that was 'under the grime of heavy industry' [9].

Her early artistic influences for such subject matter and style were Jankel Adler (1895-1949), a Jewish-Polish painter and printmaker and Polish painter, Josef Herman (1911-2000), both of whom came to the city in 1940 or 1941. Both were refugees from the Second World War (1939-1945) who Low met through activities and friendships revolving around Glasgow Unity Theatre. Joanna Drew (1929-2003), Director of Art at the Arts Council of Great Britain, observed that the influx to the UK of refugees from fascism over that period brought 'incalculable benefits to the intellectual life of this country' [10].

Glasgow Unity Theatre was based at the old site of the Refugee Centre (now the Dental Hospital on Sauchiehall Street, Glasgow) and had formed following the start of 
the Second World War, with several progressive theatre groups coming together. Cordelia Oliver described Glasgow Unity Theatre as a, 'political entity, democratically run by a diversity of members held together by an anti-Fascist aim' [11]. In the 1920s and 1930s, teaching in the painting department at Glasgow School of Art was predominantly conservative [8], with a traditional style and subject matter heavily influenced by French Post Impressionism. Adler and Herman brought an international outlook to their work and Herman in particular depicted the labour of workers, that chimed with the politics and realities of a poverty stricken Glasgow. Moreover, Adler refused to see himself as anything other than a professional artist, in a time when many artists had several jobs, bringing 'a refreshing breadth of vision and a much-needed professionalism to the artistic life of the city - or at least those who were willing to listen to him and profit from his example' [12]. John Taylor, who co-founded New Charing Cross with Low, cited the influence that Herman and Adler had on Low and Tom Macdonald, stating that, 'Herman and Adler had no doubt about being artists and I'm sure that they helped harden the resolve of both Tom and Bet to follow a similar path.' [13].

A second influence for Low during this period was John Duncan Fergusson (18741961) and Margaret Morris (1891-1980) who had, with the Second World War looming, returned from Paris to Glasgow. Both were incredibly active in leading and supporting the development of cultural life in Glasgow, with Morris forming the Celtic Ballet Company in 1940, with Fergusson its Art Director, and co-founding the New Art Club, with which Low exhibited. Fergusson was also President of the New Scottish Group, which formed in 1942.

In Low's obituary, Agnes Samuel, a Trustee of Bet Low Trust, noted that Fergusson and Morris 'befriended Low and gave support to her and other independents 
when, in 1956, they organised the first open-air exhibition at weekends on the railings of the Botanic Gardens, Glasgow. [14] Low's association with and support from the key players of Glasgow art scene, such as Fergusson, Morris, Adler and Herman, suggests that both in her grassroots activities and her developing art practice she was at the heart of Glasgow's outward-looking cultural scene during this period.

\section{1950s-1960's and the move from city to landscape}

From images of grimy, industrial smog-laden Glasgow, which Low had mostly rendered in black media on white paper, rural landscapes appeared increasingly in Low's work from the 1950s onwards. Oliver describes this shift of subject matter initially being down to the short visits Low made out of the city to Lendalfoot, a small village in South Ayrshire, and to her friends Marion and Ian Hamilton Finlay in Comrie. The exhibition From a Sketchbook of the Fifties, at Cyril Gerber Fine Art in August 1990, records this movement of loci. The thick, bold, linear brushstrokes transfer from carving out the outlines of people and tenements to the simpler vernacular of rural cottages, with colour washes creeping in.

Cordelia Oliver identified a 'study in landscape abstraction' [15] made at Lendalfoot during this period, as a 'seed of abstraction' [16] leading to a series of gouaches and oil paintings during the 1960s. These were subsequently shown in a solo exhibition in the 57 Gallery, Edinburgh, with key works including Merge and Emerge (1961) and Water and Stones (1961) taking inspiration from the interplay of surface and depth in a stream. A typed overview from University of Glasgow Special Collections [17], entitled Studio Exhibition June 1962, Bet Low, Gouache and Oil Paintings, describes the aim of this body of work, marking a departure for Low: 
These abstract paintings are constructed from the elements in Nature - Water,

Stone, Light, Movement etc. Their intent is the mood and atmosphere of Nature, not its representation. [18]

David Baxandall, (1905-1992), then Director of National Galleries of Scotland (19521970), commends her approach in BBC Edinburgh's radio programme Arts Review, stating:

These paintings of Bet Low's seemed to me to be full of genuine visual poetry[...] the connection that these paintings, abstract though they are, have with experience of things seen... it has its own natural logic. [19] By the late 1960s, following the purchase of a cottage on Hoy, Low focused solely on the Orcadian landscape. The abstract close-ups of water, movement and shapes that she had focused on in the early 1960s' offer an important bridge into the simplicity of the long view that Low experienced on Hoy; of landmasses meeting sea and sky. In the watercolour 'Black \& White Night' (1969), three areas of simple dark tone cut across the white page to denote night sky, white cloud, horizon line, sea and the slightest indication of land in the foreground.

Oliver transcribes Low's response to Orkney as follows:

It was this tremendously open, vast sky - it was all that space and the wonderful light. If you went up the hill behind the house you could stand there at the centre of Hoy and you could turn full circle and see right up to the northern isles and right down to Scotland. My one regret was that I could never paint that experience. It was like a living cyclorama. [20]

Whilst Low felt she never captured this 360 degrees view, a later work In The Hoy Hills (Orkney) (1977), originally purchased for The Scottish Arts Council collection, then gifted to Pier Arts Centre, aptly illustrates Low's ability to capture the phenomenon of seeing weather travel in over the land. In the Hoy Hills (1977) gives a weight to such a landmass, through a colour palette that renders the nearest shoulder of the hill the darkest. The light and rain flickers on the receding flanks of hills. 
[Figure 1 about here, In the Hoy Hills, (Orkney). 1977.]

Low's later pencil works have echoes of her earlier experimentation with light evident in the abstract landscapes of the early sixties. Mist by Dunkeld (date unknown) [21] show the artist's confident execution and style enabling her to render light coming through mist. The work reverberates, using the ground of the white paper as the sun itself, 'shining' between close set, repetitive downward pencil strokes. Slight changes in pressure on the pencil create heavier areas, denoting the suggestion of hill contours which amalgamate into darkness in the foreground of the composition. The suggestion of individual trees on the hillside is made through the slightest variance of direction in chosen line, at odds with the uniformity of the marks that form the majority of this piece.

In terms of Low's methodology, Cordelia Oliver called her sketches a 'form of visual note-taking... for the winter's work in her Glasgow studio'. [22] Many of these sketches, mostly in pencil, with a few as follow up gouache or watercolour paintings, are held by University of Glasgow Special Collections. In some cases a piece of paper that begins as a shopping list, 'Lentils, paper hankies', promptly becomes a sketch for an island with corresponding notes, 'Island/ man of war, muddy / only white foam, opaque sandy pink, tawny colours'. Another list begins 'Lino or carpet for my bedroom', and hidden under a sketch of sky and thin dark hill, goes on to read:

Huge evening / night sky. Cream light behind v. dark land in graduations sweeping overhead. Through slightly rosy, turq [sic. turquoise] green, turq blue up to blue then sort of blue/grey above. Stars out. Illuminated effect of great light behind hill. [23]

Most of the sketches, however, are more considered than the jotting down of an idea. The sketches are mostly up to A5, often bearing decisions on composition such as a simply drawn rectangle onto a drawing to suggest a composition. These singular works 
appear to form the artist's own index or archival system. She writes on particular sketches if she has sold the painting and to whom and also notes if it resulted in a good painting or if she made several iterations of a particular scene.

Low's paintings often have bands of colour which form segments representing the fields, hills sea and sky. She often writes notes within these corresponding to particular areas, such as 'mossy colours / yellow ochry greens / brownish with pinkish greyish moss and off-white fungus patches' [24]. These fecund notes vividly offer a colour map for to the artist to use back in the studio, as a way to fully re-enter the experience of a specific transitory moment in the landscape and its climate.

The notes sometimes contain a reference to a painting technique:

Foggy night - 1 August - All very soft misty colours - all tones of misty grey, merging, no details. Dove grey - bluish hills, lower ones towards water slightly darker, more greenish grey, as with darker strips of water. Brightest part, except for sun, is long straight strip of water at shore edge - pale, bright, slivery grey white dividing picture in two. Strip of sun brilliant gold / orange like moonlight on water. Soft and frosted when it is on light strip only. Except for sun - all picture frosted over - a pale milky grey. [25]

These descriptions are evocative, yet only exist as a private note, functioning as a tool for future execution by the artist; a route to re-enter the moment of perception in order to paint. Low does not view her words as anything other than instruction or thoughts to access a particular mood:

Marshes, rushes, water and islands. All wet, watery, island land. An island on your doorstep. Cool pools of light and wee black shadows. Black sea and towering rocks, sinking down fathoms. [26]

Low's trajectory of artistic practice could be compared to that of her contemporary, Joan Eardley (1921-1963), who like Low, had an 'urban/rural duality of her oeuvre', [27] with her Glasgow studies of children and tenements alongside later works at the coastal village of Catterline in Aberdeenshire. Biographically, both Eardley [28] and 
Low had also similarly discovered that the expected route for women graduates from art school into teacher training was not for them. They were both successful in gaining places at Hospitalfield, Arbroath, [29] (Low in 1945, Eardley in 1947), then a residential art school, taught by James Cowie. Eardley and Low's location choices sometimes crossed, predominantly through their shared friendship group, for example with both making work at Comrie in Perthshire, where Marion Fletcher and Ian Hamilton Finlay lived (Low over the earlier period 1951-1954; Eardley in 1959). Although their shared subject matter of city and landscape corresponds, as well as their desire to express their own subjectivity within landscape, their mark-making and painterly style widely differs. Where Eardley painted landscapes en plein air, expressing the power and movement of the elements through immediate gestural brush marks, Low sought to distil form to its essential elements, painting away from the landscape in her studio.

In terms of their shared choice of geographical location, Orkney, Low's work can be compared to that of Orcadian filmmaker, Margaret Tait (1918-1999). Their connection is seen most clearly through their process rather than final work. Low writes in her private visual note-taking, used as an aide-memoire for later studio paintings, 'Light rushes against blue water' [30] whilst Tait notes in Orquil Burn (1955) '... the everlasting dance and music of the water itself / are the stars'. [31] Tait, in the same poem, describes her process: 'A poem started in words goes on into the picture... Out of my own memory and thought, I find the external scenes to make a picture from'. Low's own process mirrors that of Tait's, if the word 'painting' is substituted for 'poem', with her own private notes allowing a re-entry into the experience of place when back in her Glasgow studio. 


\section{Recognition and visibility}

Returning to Low's initial trajectory through Glasgow Unity Theatre, involvement in artist-led groups such as Clyde Group, then co-founding the artist-led New Charing Cross Gallery, we see an artist whose early modus operandi was to make visible her work and that of others. This grassroots, artist-led, 'do-it-yourself' ethos could be a forbearer of artist-run gallery models such as Transmission, Glasgow, established in 1983. However, a distinct difference is that the key primary aim of New Charing Cross Gallery was to establish an environment that would primarily support a market, in this case for the sales of contemporary paintings.

In Linda Nochlin's essay Why Have There Been No Women Artists? (1971), Nochlin argues that the recognition and visibility of women artists depends, '...on the very nature of our institutional structures themselves and the view of reality which they impose on the human beings who are part of them'. [32]. Low is an artist who clearly had, and expressed her opinion on, the existing structures, which she believed excluded contemporary work. The establishment of New Charing Cross Gallery was to actively create a platform that would be differently from the existing system. Furthermore, the gallery was established in answer to what Low and Taylor saw as a specific lack in provision in Glasgow:

For a long time now, Glasgow and the West of Scotland have had no gallery willing to market the work of modern painters. This has been a great lack. In recent years, more and more people have been aware of the need for such a gallery, and now this need is being met. [33]

In 1963 as part of the promotion of the setting up of the gallery and its aims, Low wrote to David Baxandall:

The idea is to make it smart, efficient and suitable for showing modern painting to advantage as distinct from the present mausoleum like institutions we have here. [34] 
On the face of it this summary is brave, if not foolhardy, given that Baxandall ran one such institution and it somewhat illuminates Low's determined character. However, Baxandall appears not put off by her direct approach. As a presenter on Arts Review, he goes on to cover Low's activity with New Charing Cross Gallery and subsequently her art practice. Low had initially contacted Arts Review's Features Producer, George Bruce, in order to get the inaugural exhibition reviewed (the subsequent transmission was on 12 December, 1963). Bruce was preparing the information on the gallery before putting forward to Baxandall for consideration. Her correspondence with him is illuminating in that whilst she sees Glasgow galleries overlooking her type of artwork as too modern, she does not consider herself overlooked. Low comments that Bruce's terminology for the artists in the exhibition (Bet Low, John Taylor, Tom Macdonald, Douglas Abercrombie, Carole Gibbons) as 'younger Scottish artists' is incorrect, implying that they are fresh out of art school. When he argues that the phrase just means 'artists under forty', Low retaliates, 'Also, we are by no means unknown here or quite un-established or unrecognised.' [35].

This view that she presents of herself in 1963 as 'known', with a reading of 'here', as Glasgow or Scotland, can perhaps offer a different perspective to questions on recognition, visibility and at what point an artist's work becomes overlooked. From an individualistic early Twenty-first century reading of her statement, she firstly recognises herself: 'we are by no means unknown'. She also ensured she had the skills to make herself and her peers visible, with early promotional skills picked up at Glasgow Unity Theatre standing her in good stead. She knew how to promote New Charing Cross Gallery:

I took on the task of attending to all the publicity which took hours of writing several BBC programmes, TV, newspapers, invitation cards, catalogues, curtains, wine and raising a few donations. [36]. 
Low's tenacity is also shown in how she maintains such media and critic contacts over a longer period. Whilst Low had contacted Baxandall to promote the gallery, it also offered him insight in her work. In the same radio programme, Baxandall mentions Low's work in a solo exhibition at Arran Gallery (Whiting Bay, Isle of Arran, Scotland) noting that,

These paintings of Bet Low's seemed to me to be full of genuine visual poetry... the connection that these paintings, abstract though they are, have with experiences of things seen... have its own natural logic. [37]

A second critic, FW Fenton from the Daily Telegraph and Morning Mail, came up from England to review the inaugural exhibition at New Charing Cross Gallery. He returned on a further three occasions for exhibitions by J.D. Fergusson, Tom Macdonald and Joan Eardley, whose posthumous exhibition in 1965 at New Charing Cross Gallery, following her death two years earlier, proved to be a 'complete sell out' [38].

By 1963 when Low made the statement in regards to her visibility, her grassroots and peer group-led activity through the Glasgow Unity Theatre and exhibition with the New Scottish Group ensured she was recognised by her peers as well as key national artists such as Fergusson. Her early work and ethics, developed through the co-founding the Clyde Group whose manifesto was to be 'artists who are working for the community', [39] had led to organising, with Tom Macdonald, Glasgow's first Open Air Exhibition on the railings of Glasgow's Botanic Gardens in 1956. In terms of being known to the general as well as gallery-going public, this was a key initiative as it was overtly public facing. Low describes and reflects on this, in an article for the Scottish Review in 1996:

Hundreds turned out to see us. Queen Margaret Drive at junction with Great Western Road was so crowded, police were out directing traffic. People peered from buses. The BBC were filming... paintings were sold. The weekly Scotsman 
gave us a huge spread and large photographs under the heading, 'Paris on the Kelvin'. It ran for a second year but then 'died a death'.[40]

The establishment of the New Charing Cross Gallery also offered her a next step in visibility and therefore a professional trajectory. In 1964, in correspondence with Cordelia Oliver, she notes that she was finally elected as a Professional Member of the Society of Scottish Artists (her application had been turned down previously, leading her to consider this Edinburgh body was not interested in Glasgow-based artists) and was invited to become a Professional Member of the Scottish Society of Women Artists.

In her book Social Sculpture (1997), Sarah Lowndes notes that both the New Charing Cross Gallery (1963-68) and subsequently the Compass Gallery, set up by the Charing Cross Gallery's third Director, Cyril Gerber, had the main remit of 'extend[ing] the audience and market for art within Scotland'. [41] Visibility and recognition was linked to selling, both to private owners and to museum and gallery collections. Economically, the deal struck with the landlord of New Charing Cross Gallery, $\mathrm{Mr}$ Duthie, was that an agreed percentage of sales paid for the rent of this first floor space above his printers shop. Moreover, in a newsletter, dated 5 September 1968, to gallery friends notifying them of the gallery closure as the property was being sold due to $\mathrm{Mr}$ Duthie's ill health, the gallery directors state:

Numerous young painters have had their first exhibition with us and have been particularly delighted to sell some of their works to the Scottish Arts Council... and other important bodies to have purchased from the gallery include the Scottish National Gallery of Modern Art, Glasgow University, Abbot Hall Gallery Kendal, and the National Galleries of Malaysia.' (42)

During her lifetime, Low's work was acquired for both public and private collections, which is key to her perceived value as an artist then. The Scottish Arts Council (SAC) collection begun in the 1950s, through the Arts Council of Britain Scottish Committee. 
It was then dispersed in 1996 through a collecting initiative to Scottish museums and galleries, which saw several of Low's works from the SAC collection gifted to the Pier Arts Centre, Orkney. [43].

Low's visibility can be directly attributed to her own tireless activities in promotion of her work and the work of others, her contacts with newspaper and art critics, peer recognition, having key cultural figures such as Fergusson champion her work, having work in collections, and through her showing her paintings in off-site situations to engage with the public.

\section{Critical support}

Whilst I have outlined Low's carefully sustained links to national media, the support of her friend, artist and critic Cordelia Oliver cannot be underestimated. Oliver wrote about Low's work over the trajectory of her career and curated Low's 1985 retrospective at Third Eye Gallery, which remains the most comprehensive exhibition and catalogue on Low's work. Oliver was a key figure as an artist critic in Scotland, consistently writing in depth about her art school contemporaries, championing figurative work and in particular focussing on women who she felt needed more visibility. At a time where value was placed on established Royal Scottish Academy painters and those selected by institutions, Oliver supported emergent contemporary practice and new initiatives. Her support of her contemporaries over a long trajectory also positioned her as a key commentator in later decades on those emergent practitioners who were to be attributed with success and recognition. This includes Oliver's biography Joan Eardley, RSA (Mainstream Publishing, Edinburgh, 1988), published twenty-five years after Eardley's death. Oliver consistently wrote about Low's work and exhibitions, in particular for the Glasgow Herald and The Guardian. 
Oliver's selection and curation of Bet Low's 1985 retrospective at Third Eye Centre encompassed all stages of Low's practice, from city to landscape. From analysing photographs by Oliver's husband George, held at University of Glasgow Special Collections, it can be discerned as an intense hang of Low's work, with the installation including double, and in some places triple, lines of framed works. The schema is that the wall sections are shaped by the chronologies of Low's practice. Portraits of the city and its people appear predominantly on the walls lying beyond the gallery's entrance, and on free-standing wall panels in the gallery and a sequence of landscape works lie to the long wall running on the far away side of the gallery. The exhibition appears to have garnered good reviews, The art critic Clare Henry appraised the work:

Among the 160 works crowded onto the walls, my favourite is a powerful oil 'In the Hoy Hills' where mist saturates the high ridge. Here Low is at her best; neither too stylised nor too decorative [44]

R.D. Sless for Jewish Echo notes that whilst Low by the 1980s' was known for her landscapes, the exhibition gave insight into the full arc of her practice:

Her 40-year retrospective show at the Third Eye reveals other facets of artistic development. In the mid 1940s and 50s she was a committed social realist whose strongly drawn images of city people and places latterly gave way to abstractions of light pattern on water [45].

[Figure 2 about here, Installation shot of Bet Low: Paintings and Drawings 19451985, Third Eye Centre, Glasgow (1985). Photo: George Oliver. Courtesy of University of Glasgow Library, Special Collections with permission from George and Cordelia Oliver Archive.]

Bet Low: Paintings and Drawings: 1945-1985 undoubtedly marked a level of national recognition and achievement for Low in her own lifetime. Indeed, she was the only woman artist with a solo exhibition in 1985 at the Third Eye Centre. It is interesting to note that the Third Eye's exhibition programme that year began with a retrospective of 
Josef Herman Memory of Memories- The Glasgow Drawings 1940-43 (12 Jan - 3 Feb 1985). This contextualises that Low's work was equal to, and given the same platform as her mentor, moreover, that she was considered a key figure for an institution that whilst international looking, was also chronicling Glasgow and wider Scottish culture. [ 46]

\section{Low's visibility today.}

Beyond commercial gallery exhibitions, such as Compass Gallery and Roger Billcliffe Gallery, who championed her work over the 1980s and 1990s, and her significant retrospective in 1985 at Third Eye Centre, Glasgow, Low's work has been increasingly referenced, following her death in 2007, by a later generation of artists and curators in Scotland.

Her work had firstly been categorised as key in Scottish painting in 1995, with Sandy Moffat's wide-ranging selection for The Continuing Tradition: 75 Years of Painting at Glasgow School of Art that took place in the museum and studios of the Mackintosh Building on the occasion of The Glasgow School of Art's one hundred and fiftieth anniversary. Moffat, Head of Painting and Printmaking at The Glasgow School of Art from 1980 to 2005, was a key figure in the resurgence of figurative painting in Scotland in the 1980s.

Low's inclusion in later survey shows has primarily been within the curatorial thematic of women artists in Scotland, by curators including Liz Arthur, Alice Strang and Sarah Lowndes. In 2012, Lowndes curated Studio 58: Women Artists in Glasgow since World War II, in the Mackintosh Museum, The Glasgow School of Art. Rather than taking a traditional chronological approach, Lowndes made connections between the proximity of works from different generations. One of Low's works, a chalk 
drawing entitled Moon Behind Clouds (c.1950s-1960s, courtesy of the Hunterian Art Gallery) was presented, next to her peers, in the form of small ink studies by Joan Eardley and Margaret Morris [47]. Low was also included in the 2016 exhibition Modern Scottish Women: Painters and Sculptors 1885-1965, curated by Alice Strang (Senior Curator, National Galleries of Scotland), for National Galleries of Scotland. Strang notes in her catalogue essay From Annand to Zinkeisen: Forty-Five Scottish Women Painters and Sculptors (2015) that Low was a key figure as an artist who 'created their own opportunities to show and sell their work'.[48]

Both exhibition publications comprise primarily of artist biographies, suggestive of the first necessarily redemptive step to record and thus make visible overlooked histories. Indeed, in the Director's Modern Scottish Women: Painters and Sculptors 1885-196' catalogue's Director's Foreword, it was billed as 'the first major exhibition of work by women artists to be mounted by the National Galleries of Scotland' [49]. This acts as a significant statement rather than a full acknowledgement of omission, yet in a wider snapshot of the same year, omission of women artists from previous institutional programmes appear de rigour. Tate Modern had announced two new Artist Rooms by Phyllida Barlow and Louise Bourgeois 'in a bid to inspire girls and to 'redress the balance' between male and female artists, its director [Nicolas Serota] has said' [50]. This flourish of survey shows for women artists is noted in Hilary Robinson's Feminism Meets the Big Exhibition: Museum Survey Shows since 2005 [51], where she notes complexities of this reclamation model, where curatorial or institutional agendas that focus on time period or broad thematics can often override original intentions, ${ }^{6} \ldots$ in venues that are in sharp contrast to the often alternative, non-traditional venues that first hosted exhibitions informed by the women's liberation movement.' 
Whilst there is no evidence that Low saw herself as a feminist, she did consider in her time that the large museums were 'mausoleum like institutions' [52], in their unwillingess to exhibit any modern painters like herself. Indeed, this is why she coestablished New Charing Cross Gallery. Any future survey exhibition, should go further than just pinpointing in biography her grassroots activities, to explicitly implicate the mainstream institutional histories that caused such a gap.

Beyond Low's inclusion in survey shows, the archival turn of recent curatorial practice, has also offered the opportunity to return to assess practitioners like Low. The group show, Beyond Landscape (2019), curated by Andrew Parkinson at Pier Arts Centre, Orkney, selected work by Low and others from their collection (gifted by and based on the vision of artist's patron, collector and political activist Margaret Gardiner (19042005)), including Winifred Nicolson, Sylvia Whishart and Margaret Tait to celebrate the gallery's fortieth anniversary. All four works of Low's from the Pier Art Centre's collection were on show. 'Eyam Edge' (1981, gouache on paper), dates from Low's visits to Derbyshire, whilst the other three works, from the 1970s, are from Hoy, Orkney: Red Rysa (c. 1970s, oil on paper), Calm Water (at Mill Bay, Hoy) (1972, oil and gold leaf on board) and In the Hoy Hills (Orkney) (1977, oil on canvas). It is perhaps the inclusion of a suite of seven of Low's landscape paintings in Karla Black: Sculptures with paintings by Bet Low (1924-2007), (2010) Inverleith House, Royal Botanic Gardens, Edinburgh, [53] that to date offers connections and a new reading of Low's work that go beyond the formal boundaries of the landscape thematic or survey show, by implicitly tapping into and amplifying a subjective experience of landscape [54] and nature quietly present in both artist's works. Whilst Moira Jeffrey in an earlier review of Black's work states '... there's an increasing sense in Black's work that she is creating some kind of landscape' [55]), what aspects of Black's work allowed 
a different lens on that of Low's landscapes? Both practices seek to 'reduce' form to its essential materials. When re-considering Low's In The Hoy Hills (Orkney) in conjunction with Black's sculptural forms, one starts to consider the flattened flanks of the hill's corrugated planes more in terms of sculptural mass, volume, weight and shape.

The evolving synthesis of Low's work, to its essential components, is perhaps best echoed in tracking her name across her early identity papers and Unity Theatre Glasgow membership card. Elizabeth - Betty - Bet. A revisiting and reduction of name, until it settles in sound, intention and attention: Bet Low. In conclusion, Low's strippedback aesthetic, may increasingly hold a connection and relevance to contemporary artists and curators today. Whilst the limited international visibility of her work during her lifetime was mostly through exhibition surveys of Scottish art, such as the 1971 exhibition in Nice, L'Ecosse, la femme et l'art' or 'Contemporary Scottish Art which toured Denmark in 1981, it should be entirely possible for Low's work to step out of a simply a purely Scottish framing. If her work can be seen on its own terms, this offers the curatorial opportunity to expand on her approach to colour, landscape and painting language. When one considers, for example, the work of Nicolas Party (born 1980, Lausanne, Switzerland), a Glasgow School of Art MFA graduate, who eschews the extraneous details of landscape in order to explore the relationship between abstraction and representation, Low's possible relevance to different generations of artists (including Scottish women painters such as Carol Rhodes (1959-2018) and Marianne Greated) and conversely an unpacking and analysis of aspects of her work, becomes a tantalising new chapter on both a national and international stage.

\section{FOOTNOTES}

1. Alice Strang, (ed.), Modern Scottish Women: Painters \& Sculptors 1885-1965, National Galleries of Scotland, 2015, 68. 
2. The Unity Theatre Years, Russell Hunter, from Tom Macdonald: Paintings, Drawings and Theatre Designs, The Third Eye Centre, 1986, 29.

3. Acc. 12177/7, National Library of Scotland.

4. Acc 12177/9, National Library of Scotland. Typescript draft of a memoir by Bet Low, We Were Always Cold, published in the Scottish Review, 7 August 1996, 77-86.

5. Cordelia Oliver, Bet Low Paintings and Drawings, 1945-1985, Third Eye Centre, Glasgow, 10.

6. From exhibition leaflet, The Forties: Glasgow People and Places, Drawings and Paintings Tom Macdonald and Bet Low, 28 April - 19 May 1984, Cyril Gerber Fine Art.

7. Photographs of these portraits are in University of Glasgow Special Collections MS Gen 1764/C/4/1.

8. Down and Outs in Phoenix Park, Garscube Road, Indian Ink, from exhibition leaflet, The Forties: Glasgow People and Places, Drawings and Paintings Tom Macdonald and Bet Low, 28 April - 19 May 1984, Cyril Gerber Fine Art.

9. A Glasgow Sketchbook, A Quarter-Century of Observation, Louise Annand, Richard Drew Publishing, Glasgow, 1988, 7.

10. Joanna Drew and the Art of Exhibitions, Caroline Hancock, Skira Press 2018, 39.

11. Cordelia Oliver, Tom Macdonald: Paintings, Drawings and Theatre Designs, exhibition catalogue, Third Eye Centre, Glasgow, 1986, 6.

12. New Painting in Glasgow 1940-46, The Scottish Arts Council, 5.

13. Ibid, 4.

14. An Artist Remembers, John Taylor, from Tom Macdonald: Paintings, Drawings and Theatre Designs, 43.

15. Obituary, 17.12.2007, by Agnes Samuel, The Herald, Scotland.

16. Oliver, Bet Low Paintings and Drawings 1945-1985, 6.

17. Ibid, 6 .

18. MS Gen 1764/C/5/3, University of Glasgow Special Collections.

19. Acc. $12177 / 7$ National Library of Scotland.

20. Oliver, Bet Low Paintings and Drawings 1945-1985, 11.

21. Ms Gen 1764 / C / 5 / 1, University of Glasgow Special Collections.

22. Oliver, Bet Low: Paintings and Drawings 1945-1985, 10.

23. MS Gen 1964 / C / 5/ 5, University of Glasgow Special Collections.

24. MS Gen 1764/C/5/2, University of Glasgow Special Collections.

25. MS Gen 1764/C/5/5, University of Glasgow Special Collections.

26. Notes on back of a sketch, Ms Gen 1764/C/5/2, University of Glasgow Special Collections.

27. On Eardley, Alice Strang, Modern Scottish Women: Painters \& Sculptors 18851965, 13.

28. Cordelia Oliver, 'Joan Eardley', RSA, Mainstream Publishing, 1988, 18.

29. Isabel Brodie Babianska (1920-2006) also attended Hospitalfield 1941. Strang, Modern Scottish Women: Painters \& Sculptors 1885-1965, 30. 
30. Ms Gen 1764/C/5/2], University of Glasgow Special Collections.

31. Margaret Tait: Poems, Stories and Writings, Fyfield Books, Carcanet Press, 2012, 126.

32. Women Artists, The Linda Nochlin Reader, edited by Maura Reilly, Thames \& Hudson, 2015, 47.

33. 1968, newsletter to gallery friends, reporting the closure of the gallery. Acc. 12177/1, National Library of Scotland.

34. Acc. 12177/1, National Library of Scotland.

35. Ibid.

36. Ibid.

37. Ibid.

38. F.W. Fenton, 9.12.65.

39. Leaflet, The Clyde Group, Art + Peace, Festival and exhibition, MacLellan Galleries, Glasgow, September 1948. Acc. 12177/1, National Library of Scotland.

40. Typescript draft of a memoir by Bet Low, We Were Always Cold, published in the Scottish Review, 7 August 1966, 77-86.

41. P.35, in Social Sculpture: Art, Performance and Music in Glasgow, A Social History of Independent Practice, Exhibitions and Events since 1971, StopStop, 2003.

42. Acc. $12177 / 1$, National Library of Scotland.

43. The Scottish Committee of the Arts Council of Great Britain devolved to become The Scottish Arts Council (SAC) in 1967. SAC leased the Lady Artist's Club gallery, Glasgow, for exhibitions, of which New Painting in Glasgow 1940-46, 1968, was one.

44. Bet Low 7-27 September, 1985, Third Eye Centre, Glasgow: 'Bet Low', Third Eye, Glasgow, Glasgow Herald 9.9.1985.

45. 20.9.1985, 'Art Notes'.

46. In 1983, Low was one of many significant artists and writers presented by Third Eye Centre in Noise and Smoky Breath: Images of Glasgow 1900-1983, at the Mitchell Library Glasgow. In 1985, Portraits of Scottish Writers ran concurrently at Third Eye Centre (7-28 Sept 1985) with Low's Retrospective.

47. Joan Eardley, Belt Holding Up Trousers (mid 1950s), ink, conte, paper, courtesy of Glasgow Museums / Margaret Morris, Dress Design (1914), ink, conte, paper, courtesy of Glasgow Museums.

48. Strang, Modern Scottish Women, Painters \& Sculptors 1885-1965, 68.

49. Directors' Foreword (Sir John Leighton, Dr Simon Groom), 'Modern Scottish Women: Painters \& Sculptors 1885-1965)', 7.

50. Female artists are stars of the show at Tate in bid to inspire girls, Harriet Furness, the Telegraph, 14 January 2016.

51. 'OnCurating, 'Curating in Feminist Thought', Issue 29 / May 2016

52. Acc. 12177/1, National Library of Scotland.

53. 'She [Black] has chosen to show seven paintings by the artist Bet Low as part of this exhibition'. Media Release, Autumn Programme, Inverleith House, Royal Botanic Garden, Edinburgh. 
54. Singular in style, there is always in her [Low's] work a strong sense of subjective involvement of the artist herself'. The New Biographical Dictionary of Scottish Women, $2^{\text {nd }}$ edition, edited by Elizabeth Ewan, Rose Pipes, Jane Rendall, Siân Reynolds, University of Edinburgh Press, 2018, 252.

55. Art Review, The Scotsman, Karla Black, Modern Art, Oxford, 4 October 2009 ‘

\section{IMAGES}

Figure 1 .Bet Low, In the Hoy Hills (Orkney), 1977. The Pier Arts Centre Collection Photograph Alistair Peebles

Figure 2 Installation shot of Bet Low: Paintings and Drawings 1945-1985, Third Eye Centre, Glasgow (1985). Photo: George Oliver. Courtesy of University of Glasgow Library, Special Collections with permission from George and Cordelia Oliver Archive.

Bibliography

Annand, Louise, A Glasgow Sketchbook, A Quarter-Century of Observation. Richard Drew Publishing, 1988.

Carrell, Chris (ed.) Tom Macdonald (1914-1985): A Memorial Exhibition of Paintings and Drawings selected by Cordelia Oliver and Bet Low. Third Eye Centre, Glasgow, 1986.

Ewan, Elizabeth, Pipes, Rose, Rendall, Jane, Reynolds, Siân, The New Biographical Dictionary of Scottish Women. Edinburgh University Press, 2018.

Farr, Dennis, New Paintings in Glasgow 1940-46. The Scottish Arts Council, 1968.

Hancock, Caroline, Joanna Drew and the Art of Exhibitions. Skira Press, 2018.

Lowndes, Sarah, Social Sculpture: Art, Performance and Music in Glasgow, A Social

History of Independent Practice, Exhibitions and Events Since 1971. StopStop, 2003.

Neely, Sarah (ed.) Margaret Tait, Poems, Stories and Writings. Carcanet Press, 2012. 
Oliver, Cordelia, Bet Low: Paintings and Drawings 1945-1985. Third Eye Centre, Glasgow, 1985.

Oliver, Cordelia, Joan Eardley, RSA. Mainstream Publishing, 1988.

Reilly, Maura (ed.) Women Artists, The Linda Nochlin Reader. Thames \& Hudson, 2015.

Strang, Alice. (ed.) Modern Scottish Women: Painters and Sculptors 1885-1965.

Edinburgh: National Galleries of Scotland, 2015.

Thompson, Susannah Catherine, Art Writing in Scotland 1960 to 1990, (PhD diss., University of Glasgow, 2010). 
